\title{
A Non-Feminist Reading of "The Yellow Wallpaper"
}

\author{
NI Lin-na \\ Shanghai University of Medicine and Health Sciences, Shanghai China, 201318
}

\begin{abstract}
In "The Yellow Wallpaper", Gilman depicts the process of mental deterioration of a young mother who suffers from postpartum depression based on the author's own experience. This paper will try to question the traditional feminist interpretation of the story. By providing the relevant background information about the author, collecting hints in the story, and analyzing the medical situation in the 19th century, the story can be regarded, from the present perspective, as a non-feminist work.
\end{abstract}

Keywords: Postpartum depression, rest cure, feminism, story, literature review, development

\section{Introduction}

"The Yellow Wallpaper" is a short story by American author Charlotte Perkin Gilman in 1892. Written in the epistolary style, the story uses first-person narrative to describe the mental deterioration of a young mother. Suffered from postpartum depression, the unnamed protagonist of the story moves to a summer house far away from the village with her family and is asked to follow the treatment called rest cure given by her physician husband John and a famous neurologist Dr. S. Weir Mitchell. Being prohibited from reading, writing, and even seeing her baby, the young mother finally goes crazy. Concerning the fact that Gilman herself also had nearly the same experience as what she describes in the story, and she uses many detailed plots to depict the relationship between the protagonist and her husband, as well as the extent to which the regimen is strictly executed, the story is classified as one of the earliest feminist literature.

However, it is unfair to judge a literary work simply from its literal meaning and indiscriminately follow the main stream of its criticism. At the bottom of the letter which Gilman sends to Mitchell to describe her state of illness, a note written by Gilman is worth our attention -- "To save others I wrote „The Yellow Wallpaper'e. Sent Dr. Mitchell a copy. No answer. But years later I heard that he said he had changed his treatment of neurasthenia after reading T.Y.W.!!!"'(qtd. Knight 277) Judged by the words above, this story has nothing to do with feminist purpose. Gilman merely wants Mitchell to change his treatment.

Then why the story is misinterpreted as a feminist work? The answer can be found in the following three aspects. First of all, when the story was first published in 1892, feminist movements had already gained some achievements in US. According to the fact that Gilman herself is also a feminist, it "has been faulted by some critics who claim the story is nothing more than a vehicle through which she explicated her feminist social beliefs." (Short Story for Students 284) Secondly, once the feminist interpretation is formed and prevalent among the critics, several useful non-feminist details are easily ignored by the readers which can help them get rid of the bias. Thirdly, commentators tend to assess the story without taking the trouble to investigate the theoretical basis of the rest cure. Dr. Mitchell introduces this treatment based on several years' clinical observation and had successfully cured many depressed women recorded in his medical paper published in The Journal of the American Medical Association. Therefore, the rest cure is the most advanced and scientific regimen in the medical treatment of the 19 th century.

This thesis will try to question the feminist interpretation by digging out, hopefully, more information about the story, the author, and Dr. Mitchell's rest cure.

\section{The Yellow Wallpaper as a Feminist Work}

\subsection{Gilman's Life and the Academic Work}

Charlotte Perkin Gilman was born on July 3, 1860 in Hartford, Connecticut, to Frederick Beecher Perkins and Mary Fritch Perkins. Her father Frederick Beecher Perkins was a noted librarian and magazine editor. Given intelligent education from her father, Gilman enjoyed a great interest in reading and writing since childhood.

Due to the irreconcilable relationship of her parents-her mother was a typical domestic woman while her father had little affection to his family - they sought a divorce when Gilman was only nine years old. Afterward, Gilman made frequent contacts with "her independent and reform-minded great aunts: Harriet Beecher Stowe, an abolitionist and author of Uncle Tom's Cabin; Catherine Beecher, the prominent advocate of "domestic feminism"; and Isabella Beecher Hooker, an ardent suffragist." (Short Story for Students 278) Having received great influence from her aunts and witnessed the lonely and unsuccessful life of her mother, Gilman turned her attention to feminist movements and desired to affect social reform. Her early proposition was to pay for the housework.

The first marriage of Gilman did not last long. After giving birth to her daughter, she suffered from postpartum depression and left her husband Charles Walter Stetson. Later, she wrote the story "The Yellow Wallpaper". Then came the intensive activities of her feminist movement. Her work ranged from editing feminist publications to 


\section{International Journal of Science and Research (IJSR) \\ ISSN (Online): 2319-7064}

Index Copernicus Value (2013): 6.14 | Impact Factor (2014): 5.611

establishing the California Women's Congresses of 1894 and 1895 and founding the Women's Peace Party. She also lectured in the United States and England on women's rights as well as on labor reform. In 1898 she published Women and Economics: A Study of the Economic Relation between Men and Women as a Factor in Social Evolution, and then in 1909, she published a monthly journal, the Forerunner.

\subsection{Critical Review of the Story}

"The Yellow Wallpaper" was written after Gilman suffered from postpartum depression and the divorce with Charles Stetson. It was an autobiography of the author herself to some degree. Meanwhile, the process of the reception of the story was not smooth.

At first, "The Yellow Wallpaper" was refused by Horace Scudder of The Atlantic, stating "I could not forgive myself if I made others as miserable as I have made myself!" ((Short Story for Students 277) Fortunately, it was allowed to be publish by New England Magazine in 1892, but did not receive much serious attention. In 1920, the American writer William Dean Howells included the story in The Great Modern American Stories: An Anthology. At that time, early reviewers regarded the story as a horror story, for its use of Gothic conventions. It was not until Elaine R. Hedge's afterward to a 1973 edition of the story that it began receiving scholarly attention. "Hedges concluded that the story is 'one of the rare pieces of literature we have by a nineteenth-century woman which directly confronts the sexual politics of the male-female, husband-wife relationship."' (Short Story for Students 284) Enlightened by her comments, more and more later reviewers focused on the relationship between husband John and wife and classified the story as feminist literature.

\subsection{Relevant Social Background}

Such feminist interpretation could not have been made without certain social background. The second half of the nineteenth century of the United States underwent great changes. After the end of the Civil War in 1865, the US entered into an era of Reconstruction, which lasted until 1877. During this period of time, many changes occurred in culture and society. The publication of Charles Darwin's The Origin of Species in 1859 exclaimed the importance of women in the process of natural evolution. It overthrew the conventional belief and emphasized that "women were actually the hardier and more necessary sex, the one able to preserve the species." (Short Story for Students 282) Darwin's theory helped to enhance the status of women in society and push the feminist movement to a climax. Furthermore, the first organizations devoted to women's rights were founded. By 1890, such organizations claimed a total of 500,000 members.

Thus, when the story was first published in 1892, the American society was under the impact of the feminist movement which had already gained substantial achievements. Combining the fact that Gilman was a feminist and the story was written after she got a divorce and began to launch her intensive feminist activities, it is only reasonable for reviewers to interpret/ misinterpret the story as a feminist declaration.

\section{The Yellow Wallpaper as a Non-feminist Work}

\subsection{The Hints in the Story}

Although the thread of the story is the process of the protagonist's mental deterioration, and critics attribute the tragedy to the oppression from male figures, the husband for one, the story still shares some subtle descriptions about how Husband John loves and cares about his wife, which leaves readers with an implication that his treatment -- rest cure -- is unrelated with sexual discrimination.

In the beginning of the story, the narrator says, "It was very seldom that mere ordinary people like John and myself secure ancestral halls for the summer." ("The Yellow Wallpaper" 647) In other words, to cure his wife's nervous disorder, John does the things that "mere ordinary people" do to rent a big house for his wife. According to the rest cure he gives to his wife, a place to sleep is enough. It is unnecessary to spend so much time and money for such an environment. But John does. He arranges for the best solely on his wife's account. Living in this big house, which is "quite three miles from the village," ("The Yellow Wallpaper" 648) John "is away all day, and even some nights when his cases are serious." ("The Yellow Wallpaper" 649) In the nineteenth century, transportation was not so easy as it is now. As most people lived in town, John, a physician, must have taken trouble to spend quite a long time on the road to work, and even to spend night there.

Following the development of the story, the narrator records that, regardless of the energy-consuming work, John never forgets to show concern over his wife. He asks his sister to come to do the house chores and he takes care of all the rest. Every time his wife comes up with horrible imaginations, John would explain and try to calm her down, even in the midnight.

The young mother also says, when John is at home, "He took me in his arms and called me a blessed little goose." ("The Yellow Wallpaper" 649) Moreover, when she is exhausted, "Dear John gathered me up in his arms, and just carried me upstairs and laid me on the bed, and sat by me and read to me till it tired my head." ("The Yellow Wallpaper" 652)

Katherine R. Allen stated, "Feminism encompasses a variety of perspectives," and one of the perspectives to identify a feminist theme is "the assumption that women are exploited, devalued, and oppressed." (29) In "The Yellow Wallpaper", the story never shows any details that the young mother is "exploited, devalued, and oppressed." If she is, her husband would not rent a big house for her, call her "a blessed little goose," and take her to the most famous doctor. Thus, the story conveys the possibility that it could not have been a feminist piece. It could not be her husband's intention to ill treat, not to say oppress, his wife.

\section{Volume 4 Issue 12, December 2015}




\section{International Journal of Science and Research (IJSR) \\ ISSN (Online): 2319-7064}

Index Copernicus Value (2013): 6.14 | Impact Factor (2014): 5.611

\subsection{The Unreliability of the Language}

"An Unreliable narrator is a narrator, whether in literature, film, or theatre, whose credibility has been seriously compromised," (Frey 107) and "whose characteristics change in the course of the works they narrate." (Booth 156-57)"On the basis of social and literature conventions, according to the semantic classification of unreliable narrator, the heroine belongs to one of the four major types of the unreliable narrator -- a madwoman (the other three types are vagrant, children, and clown)." (Xiao 65) The story is written as a diary of this lonely, depressed, oversensitive, and splitminded woman. She judges everything around through an abnormal perspective. Therefore, the evaluation of the events should be suspected.

In 2007, James Phelan raised two types of unreliable narration - estranging unreliability and bonding unreliability - on the basis of the criterion of the distance between the narrator and the authorial audience, in his paper "Estranging Unreliability, Bonding Unreliability, and the Ethics of 'Lolita"' collected in the journal Narrative. (Phelan 225) The former type widens the distance between the narrator and the authorial audience, while the later reduces such distance. In "The Yellow Wallpaper", the protagonist skillfully uses these two types of unreliable narration to attract the audience's attention and keep the audience following her imagination.

On the ethical level, the audience most probably cannot agree with the protagonist in her imagination as the woman behind the yellow wallpaper. The distance between the narrator and the audience exists. However, in order to make up for this illogical thinking, the narrator uses some logical descriptions to reduce the distance with its audience. At the very start, she introduces the fact that John is a decent physician who is willing to rent a colonial mansion for three months for his wife, and he is such a good husband who takes all care from her. Then the narrator confesses that she is a nervous woman indulged in unrealistic imagination. By taking in these facts, the audience would easily believe in narrator's words and sympathize with her. With the development of the story, the narrator gradually makes use of this trust to focus the readeres attention on the yellow wallpaper and make them buy the story she tells and identify with her:

One of those sprawling flamboyant patterns committing every artistic sin...the lame uncertain curves commit suicide...destroy themselves in unheard of contradictions...The color is repellent, almost revolting...It is dull yet lurid orange in some places, a sickly sulfur tint in others...Up and down and sideways they crawl, and those absurd, unblinking eyes are everywhere...a kind of "debased Romanesque"...the sprawling outlines run off in great slanting waves of optic horror, like a lot of wallowing seaweeds in full chase...There are things in that paper that nobody knows but me, or ever will. Behind that outside pattern the dim shapes get clear every day...And it is like a woman stooping down and creeping about behind that pattern...The faint figure behind seemed to shake the pattern, just as if she wanted to get out...The color is hideous enough, and reliable enough, and infuriating enough, but the pattern is
torturing...I didn"t realize for a long time what the thing was that showed behind, that din sub-pattern, but now I am quite sure it is a woman. By daylight she id subdued, quiet. I fancy it is the pattern that keeps her so still...A yellow smell...The woman behind shakes it! Sometimes I think there are a great many women behind, and sometimes only one, and she crawls around fast, and her crawling shakes it all over. Then in the very bright spots she keeps still, and in the very shady spots she just takes hold of the bars and shakes them hard. And she is all the time trying to climb through. But nobody could climb through that pattern - it strangles so...I think that woman gets out in the daytime!...I can see her out of every one of my windows!...I see her on that long road under the tress, creeping along, and when a carriage comes she hides under the blackberry vines...I don't like to LOOK out of the windows even - there are so many of those creeping women, and they creep so fast. I wonder if they all come out of that wallpaper as I did?...It is so pleasant to be out in this great room and creep around as I please!..."I've got out at last," said I, "in spite of you and Jane. And I've pulled off most of the paper, so you can't put me back!("The Yellow Wallpaper" 647-57)

At first, although the protagonist uses a host of personifications, she simply describes the lines and the color of the wallpaper. Then, by telling the readers that no one pays any attention to the paper except her, she successfully turns herself to be the authority of the yellow wallpaper, and gains the trust from the readers. Once holding the power of speech, she claims that she discovers the secret of the paper - a woman behind it. She fixes her attention to the trapped woman and observes her behaviour all day long. She gradually synthesizes her own feeling with that woman, reducing the distance between the audience by describing the thoughts of the woman like describing her own thoughts. Finally she goes crazy, successfully making herself to be the woman she imagined without the doubts from the readers.

By reevaluating the unreliability of the language, we can see that the feminist criticism founded on the protagonist's way of thinking turns out to be unreasonable. The following section will enumerate some of the evidences to support the assumption that the story is a non-feminist one.

\section{Textual Evidences in Support of a Non- feminist Interpretation}

\subsection{Dr. S. Weir Mitchell}

Once in the story, the protagonist mentions that "John says if I don't pick up faster he shall send me to Weir Mitchell in the fall." ("The Yellow Wallpaper" 650) Concerning the fact that Dr. Mitchell and his rest cure were the objects of feminist criticism, a study of Dr. Mitchell and his rest cure is essential to question the feminist standpoint.

Dr. S. Weir Mitchell was one of the most famous and wellrespected neurologist in America in the nineteenth century. Mitchell was born in a medical family in Philadelphia, Pennsylvania. His father was physician John Kearsley Mitchell. Being influenced by the family, Mitchell got M.D.

\section{Volume 4 Issue 12, December 2015}




\section{International Journal of Science and Research (IJSR) \\ ISSN (Online): 2319-7064}

Index Copernicus Value (2013): 6.14 | Impact Factor (2014): 5.611

at Jefferson Medical college. Due to lack of funds, Weir Mitchell first began his career in immunology, and did excellent experiments on snake venom. Then the civil war provided him with the opportunity for extensive study of nervous injuries. "Thenceforward all his powers, all his energies, were devoted to neurology--then almost a new department of medicine with which we are now so familiar." (Keen 257) In 1867, Mitchell joined forces with several orthopaedic doctors to found a small "Orthopaedic Hospital", and in 1893, the name was lengthened to "The Orthopaedic Hospital and Infirmary for Nervous Diseases". After introducing the Weir Mitchell Rest Cure, his reputation was known not only all over the United States, but to foreign countries as well. His theory became the most advanced in this newly developed field.

When Dr. William Williams Keen, the first brain surgeon in the United States, who worked closely with six American presidents, addressed at the Dedication of the Mitchell Memorial Building of the Philadelphia Orthopaedic Hospital and Infirmary for Nervous Diseases, he confirmed that Weir Mitchell was "the most original, fertile, stimulating medical man" (Keen 256) he had ever met either in America or elsewhere. He also praised Mitchell's strict attitude towards patients. He said,

To begin with a new patient; to observe Mitchell's careful cross examination as to the earliest symptoms; his minute following up of even a stray hint which to an ordinary man would have meant little or nothing, but which to Mitchell was a veritable guide post to the right road; to hear him compare or contrast this case with other similar or opposite cases garnered by an accurate memory from the myriad cases seen one year, five years, ten or even twenty years before; to see how he inevitably put his finger on the exact central fundamental lesion which to others was obscured by the many surrounding minor symptoms; a diagnosis made often seemingly by intuition; to follow his treatment until betterment or cure or in rare cases death closed the scene; this was a liberal education in itself. (Keen 258)

These words highly evaluate Dr. Mitchell's medical skill and his "careful cross examination," which raises the assumption that his rest cure is not a causal treatment, and it has a host of valid clinical cases to support its effectiveness.

Moreover, Dr. Mitchell never denied the importance of education to women. He was more open-minded than many people of his day. "I most honestly believe that the woman is the better in mind and morals for the larger training, better if she marries, and far better and happier if it chances that she does not....The majority of healthy young women ought to be able to bear the strain." (qtd. Poirier 19) Mitchell clearly saw the restrictions marriage brought to a wife and how it endangers the health of a woman for the insensitive and ignorant husband who cares more about his own business.

However, one of the facts that could not be ignored is that when Gilman, like the protagonist in the story, turns to Mitchell for help, Dr. Mitchell was already 50 years old, and was at the top of his fame. He summered in fashionable and expensive Newport, Rhode Island, and in his leisure time, he wrote fiction and poetry, which later contributed to his attainments in literature.

\subsection{Weir Mitchell Rest Cure and its application to Gilman}

With the unfolding of neurology and the limited medical knowledge of psychiatry and psychology in the nineteenth century, doctors believed that all mental illness could be cured through "a constant source of irritation between these three emerging disciplines." (Poirier 16) Based on the observation in Orthopaedic Hospital, Mitchell recognized that many of the results of nervous diseases, especially of their palsies, resulted in deformities and disabilities which could only be remedied or alleviated by orthopaedic surgery. Thus, he "believed that science would ultimately find a somatic cause for all mental illness." (Poirier 16)

Mitchell first described the rest cure in 1873, having successfully applied it to locomotor ataxia, a nervous disease. With further research, he combined the rest cure treatment with gunshot wounds and other nervous diseases. He cited his initial case of a nervous woman who "had tired out the doctors, and exhausted drug-shops and spas and travel, and outlived a nurse or two." (qtd. Poirier 17 ) In his opinion, body and mind are closely related with each other, though it seems ridiculous for us today. He wrote, "Injurious physical, moral and mental habits help to create or keep up disease, whether organic or not." (qtd. Poirier 17) Then he put up his conclusion that, "You cure the body and somehow find that the mind is also cured." (qtd. Poirier 17 )

Examining the cases of those nervous women, Mitchell found a common feature that they are all pale, thin and rundown, like anemia. This symptom belongs to an illness called neurasthenia, which swept the U.S. and Europe in the late $1800 \mathrm{~s}$ and persevered until the 1920s. To neurasthenia, it can be feigned into two types. If a person consciously pretends to be neurasthenia, most of cases, he wants to escape from the work; if a person unconsciously pretends to be neurasthenia, this kind of nervous disease is called hysteria. Gilman claims that she is hysteric, an unconscious nervousness, which cannot be controlled by herself. Looking over Mitchel's case histories most of the nervous women were judged to be so. "In women neurasthenia also came from overwork, but usually from nursing sick family members, study school lessons too intently during a time of important hormonal activity, or staying out too late too often at social events." (qtd. Poirier 18) It is exactly the basis for Gilman's rest cure regimen. In her letter to Dr. Mitchell, Gilman described that she began to feel depressed after she gave birth to her daughter. She nursed the baby in tears. Then she made a wild determination, left her family and daughter to start to visit her friends in California. Spending the winter there, she recovered from the nervousness. When she came back home, she had a severe cold, and it infected her baby. She had to nurse the baby day and night with sick body. Three days later, her mental condition broke down again, getting worse and worse.

For Mitchell's point of view, since "science would ultimately find a somatic cause for all mental illness," rest and food can give the body a chance to rebuilt red blood cells and regain

\section{Volume 4 Issue 12, December 2015}




\section{International Journal of Science and Research (IJSR) \\ ISSN (Online): 2319-7064}

Index Copernicus Value (2013): 6.14 | Impact Factor (2014): 5.611

weight and energy. As he reported in his medical work, Fat and Blood, "I am daily amazed to see how kindly nervous and anemic women take to this absolute rest...[T] he sense of comfort which is apt to come about the fifth or sixth day, -the feeling of ease, and the ready capacity to digest food, and the growing hope of final cure, fed as it is by present relief." (qtd. Poirier 18) Once the patient recovered physically, her mind also regained the optimism towards life.

More importantly, Mitchell once made the rest cure treatment to himself and got cured, which gave him more confidence in treating other patients. As a student, he entered into the medical college against the will of his father. Being an industrious man, he concentrated himself to the work until he suffered a nervous collapse in 1864 . He recorded that it is "an attack of neurasthenia with grave insomnia." Then he successfully treated himself with rest cure.

Thus, Weir Mitchell Rest Cure represents the most advanced and persuaded treating method to nervous women of his day. The information that Gilman gave to Dr. Mitchell about herself satisfies the prerequisites for mental collapse. For Mitchell himself is not a stereotypical man who opposes feminism and the education of women, the regimen he gave to Gilman is appropriate on that condition.

\subsection{The Real Problem of Gilman}

Since Dr. S. Weir Mitchell should probably not be blamed for his treatment, why Gilman cannot recover from the illness? The answer lies in the letter Gilman gave to Mitchell.

According to Gilman's own words, being influenced by her father's solitary disposition, she seems weird to the others and does not have friends since childhood. The only friend, a girl, died when Gilman was 21 years old. Gilman described the death of her friend as "a desperate grief" to her. Then she met her first husband, the only lover. She says, "after two years of terrible struggle and agony of mind I was weak enough to marry him." (qtd. Knight 273) After giving birth to their daughter, she "had terrible fits of remorse and depression all through the time, but thought nothing of them as I had had the same in the two years torture called courtship." (qtd. Knight 273)

It is obviously that Gilman had no feeling towards her husband. She thought it was a torture to stay with him, not to mention carrying his baby. It also explains why Gilman would get well once she left her family. All her hysteria, her depression comes from the marriage without love.

\section{Conclusion and Summary}

In summary, "The Yellow Wallpaper" should not be a feminist story. Gilman only wants to use the story to warn both patients and Dr. Mitchell about the incorrect treatment, as she said, "It was not intended to drive people crazy, but to save people from being driven crazy, and it worked." (Gilman) Former feminist criticism inappropriately connects the story with the author's feminist standpoint, misinterprets the descriptions in the story, and ignores the undeveloped medical technology. Based on the information which Gilman gave to Mitchell, her symptom is the same with the majority cases of nervous women who were cured under the rest cure. Thus, using rest cure has no sexual discrimination to the protagonist as well as to Gilman herself. Therefore, it is unreasonable for reviewers to follow others and regard the story as feminist literature.

\section{References}

[1] Booth, Wayne C.. The Rhetoric of Fiction. Chicago: Chicago UP, 1983. Print.

[2] Frey, James N. How to Write a Damn Good Novel, II. New York: St. Martin's, 1994. Print.

[3] Gilman, Charlotte Perkins. "Why I Wrote 'The Yellow Wallpaper'." The Forerunner (1913). Print.

[4] ---. "The Yellow Wallpaper." The New England Magazine Jan. 1892: 647-57. Print.

[5] Hayne, Barrie. "S[ilas]. Weir Mitchell (1892-1914)." American Literary Realism 2.2 (1969): 149-55. Print.

[6] Keen, William Williams. "Address at the Dedication of the Mitchell Memorial Building of the Philadelphia Orthopaedic Hospital and Infirmary for Nervous Diseases." Science, 44.1130 (1916): 255-59. Print.

[7] Knight, Denise D. "All the Facts of the Case': Gilman's Lost Letter to Dr. S. Weir Mitchell." American Literary Realism 37.3 (2005): 259-77. Print.

[8] Mitchell, S. Weir. Doctor and Patient. "All the Facts of the Case': Gilman's Lost Letter to Dr. S. Weir Mitchell." Ed. Denise D. Knight. Champaign: Illinois UP, 2005. 149. Print.

[9] ---. "The Treatment by Rest, Seclusion, etc., in Relation to Psychotherapy" Ed. Denise D. Knight. Champaign: Illinois UP, 2005. 149. Print.

[10]Phalen, James. "Estranging Unreliability, Bonding Unreliability, and the Ethics of Lotita." Narrative, May 2007: 222-38. Print.

[11] Short Story for Students. Michigan: Gale, 2002. 277-93. Print.

[12] Sun Yanfang , "Unreality Constructs Reality --the Reading of the Unreal Story 'The Yellow Wallpaper"' Jounal of Qujin Normal University, No.5, 2007. Print.

[13]"S. Weir Mitchell." The British Medical Journal 1.3141 (1921): 396. Print.

[14] Suzanne Poirier. "The Weir Mitchell Rest Cure: Doctor and Patients." Women's Studies 10 (1983): 15-40. Print.

[15]Xiao Xiangyang, "The Unreliable Narration of 'The Yellow Wallpaper' and Its ethics" , Jounal of Hunan University of Science and Engineering, No. 2, 2010. Print. 